\title{
STRUKTUR KOMUNITAS EKOSISTEM MANGROVE DI KAWASAN PESISIR KOTA MUKOMUKO KABUPATEN MUKOMUKO PROVINSI BENGKULU
}

\author{
Zamdial, Dede Hartono, Yar Johan \\ Program Studi IImu Kelautan, Fakultas Pertanian, Universitas Bengkulu, \\ Bengkulu, Indonesia \\ E-mail : Zamdial_et@yahoo.co.id
}

Received March 2019 Accepted April 2019

\begin{abstract}
ABSTRAK
Mangrove merupakan salah satu ekosistem penting di wilayah pesisir Kota Mukomuko. Ada berbagai macam aktivitas manusia di kawasan ekosistem hutan mangrove di pesisir Kota Mukomuko yang dikhawatirkan dapat menimbulkan dampak negatif. Penelitian ini dilakukan dari bulan Juli 2018 sampai dengan September 2018. Tujuan penelitian untuk mendeskripsikan struktur komunitas mangrove di kawasan pesisir Kota Mukomuko Provinsi Bengkulu. Penelitian ini dilakukan dengan metode survei. Pengambilan data vegetasi mangrove dilakukan dengan menggunakan transek garis dengan ukuran $10 \mathrm{~m} \times 10 \mathrm{~m}$, pada tiga stasiun berbeda, yang meliputi Kelurahan Bandar Ratu, Desa Ujung Padang dan Kelurahan Pasar Mukomuko. Analisis data penelitian dilakukan dengan metode statistik deskripitif. Hasil penelitian menunjukkan bahwa secara keseluruhan nilai kerapatan (Di), frekuensi jenis $(\mathrm{Fi})$, tutupan $(\mathrm{Ci})$ dan indeks nilai penting (INP) tergolong baik, namun nilai keanekaragaman jenis tergolong rendah, dikarenakan ada jenis mangrove yang lebih mendominasi di kawasan tersebut. Indeks nilai penting (INP) mangrove menunjukkan peran vegetasi mangrove di kawasan pesisir Kota Mukomuko tergolong tinggi dalam menjaga lingkungan pesisir, baik tingkatan pohon, anakan maupun semai.
\end{abstract}

Kata kunci : Kawasan Pesisir, Komunitas, Mangrove, Mukomuko

\section{ABSTRACT}

\section{STRUCTURE COMMUNITY OF MANGROVE ECOSYSTEM IN} COASTAL AREA OF MUKOMUKO CITY, MUKOMUKO DISTRICT, BENGKULU PROVINCE. Mangroves are one of the important ecosystems in the coastal area of Mukomuko City. There are various kinds of human activities in the mangrove forest area on the coast of Mukomuko City which is feared to have a negative impact. This research was 92 
conducted from July 2018 to September 2018. The objective of this research was to describe the mangrove community structure in the coastal area of Mukomuko City, Bengkulu Province. This research was conducted by survey method. Data collection on mangrove vegetation was carried out using line transects with sizes of $10 \mathrm{~m} \times 10 \mathrm{~m}$, at three different stations, which included Bandar Ratu Village, Ujung Padang Village and Pasar Mukomuko Village. Analysis of research data was carried out by descriptive statistical methods. The results of the study indicate that overall the density value (Di), frequency type (Fi), cover (Ci) and important values index (INP) were classified as good, but the value of species diversity is relatively low, because there are mangrove species that dominated more in the area. The importance value index (INP) of mangroves indicates the role of mangrove vegetation in the coastal area of Mukomuko City is high in maintaining the coastal environment, both tree level, tillers and seedlings.

Keywords : Coastal Environment, Community, Mangrove, Mukomuko

\section{PENDAHULUAN}

Kabupaten Mukomuko merupakan salah satu kabupaten di Provinsi Bengkulu yang mempunyai wilayah pesisir dengan panjang garis pantai sekitar 98,2 km (BPS Kabupaten Mukomuko, 2016). Sepanjang wilayah pesisir Kabupaten Mukomuko terdapat beragam potensi sumberdaya hayati kelautan dan perikanan yang menjaditumpuan penghidupan masyarakat. Salah satu potensi sumberdaya hayati tersebut adalah ekosistem mangrove.

Ekosistem mangrove di Kabupaten Mukomuko tidak begitu banyak, letaknya terpencar-pencar serta tidak begitu luas. Namun, keberadaan mangrove sangatlah penting untuk menjaga keberlangsungan hidup sumberdaya ikan dan juga keberadaan biota disekitar mangrove. Sepanjang pesisir pantai Kabupaten Mukomuko, ekosistem mangrove dapat dijumpai di Kota Mukomuko, dekat muara Selagan, Desa Bandar Ratu, Desa Pasar Mukomuko dan di Desa Air Hitam (Hartono et al., 2014).

Pemanfaatan sumberdaya wilayah pesisir oleh manusia dari waktu ke waktu terus meningkat. Intensitas pemanfaatan potensi sumberdaya wilayah pesisir sering tidak memperhatikan daya dukung dan azas-azas pemanfaatan sumberdaya alam secara optimal dan berkelanjutan. Ancaman terhadap ekosistem mangrove di kawasan pesisir Kota Mukomuko yaitu adanya konversi lahan untuk lokasi pembangunan dan pemukiman. Hal ini dikarenakan semakin sempitnya wilayah pemukiman di perkotaan dan bertambahnya kebutuhan untuk pemukiman dari waktu ke waktu.

Ekosistem mangrove di kawasan pesisir Kota Mukomuko perlu dijaga kelestariannya baik secara ekologi maupun biologi, sehingga perlu adanya sebuah penelitian tentang strukur komunitas mangrove di 
kawasan pesisir Kota Mukomuko Kabupaten Mukomuko Provinsi Bengkulu, meliputi kerapatan jenis (Di), kerapatan relatif jenis (RDi), frekuensi jenis (Fi), frekuensi relatif jenis (RFi), penutupan jenis (Ci), penutupan relatif jenis ( $\mathrm{RCi}$ ), indeks nilai penting (INP) mangrove, indeks dominansi (C) dan indeks keanekaragaman ( $\left.H^{\prime}\right)$. Penelitian struktur komunitas mangrove ini merupakan salah satu aspek penting untuk mengetahui kondisi suatu ekosistem pesisir dan melihat seberapa besar ekosistem mangrove itu berperan penting terhadap lingkungan khususnya di kawasan pesisir Kota Mukomuko, Kabupaten Mukomuko Provinsi Bengkulu.

\section{MATERI DAN METODE}

\section{Waktu dan Tempat Penelitian}

Penelitian ini dilaksanakan dari bulan Juli 2018 sampai dengan September 2018 di ekosistem mangrove pesisir Kota Mukomuko, Kabupaten Mukomuko Provinsi Bengkulu. Pengamatan dilakukan pada tiga stasiun yang mewakili kawasan pesisir Kota Mukomuko, meliputi Kelurahan Bandar Ratu, Desa Ujung Padang dan Kelurahan Pasar Mukomuko.

\section{Pengambilan Data}

Pengambilan data mangrove dilakukan pada 3 (tiga) stasiun yang berbeda, dimana pada setiap stasiun terdapat 3 (tiga) garis transek dan pada 1 (satu) garis transek terdapat 3 (tiga) petak (plot) pengambilan sampel berukuran $10 \mathrm{~m} \times 10 \mathrm{~m}$. Jalur transek pengamatan dimulai dengan arah tegak lurus dari arah laut ke arah daratan sepanjang adanya mangrove. Masing-masing transek dalam sub stasiun penelitian memiliki jarak \pm 100 meter, sedangkan jarak antar stasiun yaitu \pm 300 meter.

Pengukuran kualitas air yang dilakukan secara langsung di lapangan pada setiap stasiun penelitian, meliputi parameter suhu, salinitas, oksigen terlarut (DO), dan kecerahan perairan, sedangkan pengukuran kandungan nitrit, nitrat dan fosfat dilakukan di laboratorium, dimana sampel air diambil dari setiap stasiun penelitian dan selanjutnya dimasukkan ke dalam botol sample untuk kemudian disimpan di dalam cool box. Pengukuran suhu, salinitas dan oksigen terlarut (DO) dilakukan dengan menggunakan Multy Parameter Analyser, sedangkan pengukuran kecerahan perairan dilakukan dengan menggunakan Secchi Disk. 


\section{Analisis Data}

\section{Kerapatan Jenis (Di)}

Kerapatan jenis (Di) merupakan jumlah tegakan jenis ke-i dalam suatu unit area. Penentuan kerapatan jenis menggunakan rumus (Bengen, 2000) :

$$
\mathrm{Di}=\frac{n i}{A}
$$

Dimana : Di adalah kerapatan jenis ke-i, ni adalah jumlah total individu ke$\mathrm{i}$, dan $\mathrm{A}$ adalah luas total area pengambilan contoh $\left(\mathrm{m}^{2}\right)$.

\section{Kerapatan Relatif (RDi)}

Kerapatan relatif (RDi) merupakan jumlah perbandingan antara jumlah jenis tegakan jenis ke-1 dengan total tegakan seluruh jenis. Penentuan kerapatan Relatif (RDi) menggunakan rumus (Bengen, 2000) :

$$
\mathrm{RDi}=\left[\frac{n i}{\sum n}\right] \times 100
$$

dimana: RDi adalah kerapatan relatif, ni adalah jumlah total dan $\sum n$ adalah total tegakan seluruh jenis.

\section{Frekuensi Jenis (Fi)}

Frekuensi jenis ( $\mathrm{Fi}$ ) yaitu peluang ditemukan suatu jenis ke-i dalam semua petak contoh dibanding dengan jumlah total petak contoh yang dibuat. Penentuan frekuensi jenis (Fi) menggunakan rumus (Bengen, 2000) :

$$
\mathrm{Fi}=\frac{p i}{\sum f}
$$

dimana : Fi adalah frekuensi jenis ke-i, pi adala hjumlah petak contoh dimana ditemukan jenis ke-i dan $\sum F$ adalah jumlah total petak contoh yang dibuat (3 plot).

\section{Frekuensi Relatif (RFi)}

Frekuensi relatif (RFi) adalah perbandingan antara frekuensi jenis ke-i dengan jumlah frekuensi seluruh jenis. Penentuan frekuensi relatif (RFi) menggunakan rumus (Bengen, 2000) :

$$
\mathrm{RFi}=\left[\frac{F i}{\sum F}\right] \times 100
$$


dimana : RFi adalah frekuensi relatif jenis, Fi adalah frekuensi jenis ke-i $\operatorname{dan} \sum F$ adalah jumlah total petak contoh yang dibuat (3 plot).

\section{Penutupan jenis (Ci)}

Penutupan jenis $(\mathrm{Ci})$ adalah luas penutupan jenis ke-i dalam suatu unit area tertentu. Penentuan penutupan jenis $(\mathrm{Ci})$ menggunakan rumus (Bengen, 2000) :

$$
\mathrm{Ci}=\frac{\sum B A}{A}
$$

dimana : $\mathrm{Ci}$ adalah Penutupan jenis, $\sum B A$ adalah $\pi \mathrm{d}^{2} / 4(\mathrm{~d}=$ diameter batang setinggi dada $(\mathrm{d}=$ keliling/ $\pi), \pi=3,14)$ dan $A$ adalah luas total area pengambilan contoh $\left(\mathrm{m}^{2}\right)$.

\section{Penutupan Relatif (RCi)}

Penutupan relatif $(\mathrm{RCi})$ yaitu perbandingan antara penutupan jenis ke-i dengan luas total penutupan untuk seluruh jenis. Penentuan penutupan relatif (RCi) menggunakan rumus (Bengen, 2000) :

$$
\mathrm{RCi}=\left(\frac{C i}{\sum C}\right) \times 100
$$

dimana : Rci adalah penutupan relatif, $\mathrm{Ci}$ adalah penutupan jenis ke-i dan $\mathrm{C}$ adalah penutupan total untuk seluruh jenis.

Indeks Nilai Penting (INP)

Perhitungan indeks nilai penting mangrove menggunakan rumus sebagai berikut (Sofian $d k k$. 2012) :

1. Untuk tingkat pohon menggunakan rumus :

$$
\mathrm{INP}=\mathrm{RDi}+\mathrm{RFi}+\mathrm{RCi}
$$

2. Untuk tingkat Semai dan Pancang menggunakan rumus :

$$
\mathrm{INP}=\mathrm{RDi}+\mathrm{RFi}
$$

dimana : INP adalah indeks nilai penting, RDi adalah kerapatan relatif, RFi adalah frekuensi relatif, dan $\mathrm{RCi}$ adalah penutupan relatif.

\section{Indeks Dominansi}

Menurut Odum (1993) status kondisi komunitas dapat ditentukan dengan menggunakan indeks dominansi. 


$$
\mathrm{D}=\sum_{i=1}^{S}\left[\frac{N i}{N}\right]^{2}
$$

dimana : D adalah indeks dominansi-Simpson, $N$ i adalah jumlah individu jenis ke-i, $\mathrm{N}$ adalah jumlah total individu, dan $\mathrm{S}$ adalah jumlah jenis.

\section{Indeks Keanekaragaman}

Keanekaragaman ditentukan dengan menggunakan rumus kenekaragaman menurut Shannon-Wiener (1984) dalam Bengen (2000) sebagai berikut :

$$
\mathrm{H}^{\prime}=\sum_{i=1}^{S}\left(\frac{n 1}{N}\right) \operatorname{In}(n 1 / N)
$$

dimana: H'adalah indeks keanekaragaman, $\mathrm{n} 1$ adalah nilai tiap individu ke-i, $\mathrm{N}$ adalah total nilai dan $\mathrm{S}$ adalah jumlah genera.

\section{HASIL DAN PEMBAHASAN}

\section{Komposisi Vegetasi Mangrove}

Komposisi vegetasi mangrove yang ditemukan di kawasan pesisir Kota Mukomuko Kabupaten Mukomuko sebanyak 5 (lima) jenis, 4 (empat) jenis mangrove sejati yaitu Bruguiera gymnorrhiza, Rhizopora spp., Sonneratia spp., Xylocarpus granatum dan 1 (satu) jenis tumbuhan nonmangrove yaitu Nypa fruticans yang biasa berasosiasi pada ekosistem mangrove (Tabel 1).

Dari 3 stasiun pengamatan komposisi tumbuhan mangrove paling banyak ditemukan pada Stasiun I di Kelurahan Bandar Ratu, yang posisinya lebih dekat pertemuan dua muara sungai, yaitu Sungai Air Selagan dan Sungai Air Manjuto.

Tabel 1. Komposisi Vegetasi Mangrove di Kabupaten Mukomuko Provinsi Bengkulu

\begin{tabular}{clccc}
\hline \multirow{2}{*}{ No } & \multirow{2}{*}{ Jenis Mangrove } & \multicolumn{3}{c}{ Stasiun } \\
\cline { 2 - 4 } & Bruguiera gymnorrhiza & I & II & III \\
\hline 1 & Rhizopora spp. & + & - & - \\
3 & Sonneratia spp. & + & - & - \\
4 & Xylocarpus granatum & + & - & + \\
5 & Nypa fruticans * & - & + & + \\
Sumber : Hasil pengukuran langsung data primer (2018) \\
Keterangan : * Jenis tumbuhan non-mangrove. \\
$\quad$ + Ada jenis mangrove. \\
- Tidak ada jenis mangrove.
\end{tabular}


Vegetasi mangrove sejati paling banyak ditemukan pada stasiun I. Banyaknya mangrove sejati di stasiun ini, diduga karena kondisi lingkungan baik substrat maupun salinitas masih bisa ditoleransi oleh berbagai jenis tumbuhan mangrove. Stasiun I terletak di Kelurahan Bandar Ratu, memiliki kondisi mangrove heterogen jika dibandingkan dengan kedua stasiun lainnya di Desa Ujung Padang (Stasiun II) dan Kelurahan Pasar Mukomuko (Stasiun III) dengan kondisi mangrove homogen, dimana terdapat satu jenis mangrove yang mendominasi di wilayah tersebut. Vegetasi mangrove yang paling umum ditemukan di kawasan pesisir Kota Mukomuko yaitu Rhizopora spp.dan Sonneratia spp. Menurut Sofian $d k k$. (2010) jenis ini memiliki keunggulan dalam menyesuaikan diri dengan kondisi lingkungannya.

Ekosistem hutan mangrove di Kota Mukomuko dikategorikan sebagai riverine mangrove, karena terletak disepanjang bantaran sungai. Jenis mangrove yang banyak tumbuh adalah Rhizopora yang termasuk kelompok red mangrove. Menurut Sykes (2007), daerah tepian sungai yang basah sebagian besar terdiri dari jenis mangrove merah (red mangrove) dengan akar penyangga memanjang ke dalam air dan mengakar di dalam, lumpur yang lunak.

Tumbuhan mangrove yang juga banyak ditemukan di Kota Mukomuko adalah dari jenis Sonneratia atau pedada/pedado. Jika dilihat dari habitatnya dan nilai salinitas lingkungan perairan tempat tumbuh mangrove yang rendah (4-5\%), jenis Sonneratia yang terdapat di ekosistem mangrove Kota Mukomuko adalah Sonneratia caseolaris. Marisa and Sarno (2015), menyebutkan bahwa setiap jenis memiliki zonasi salinitasnya sendiri; S. caseolaris ditemukan pada salinitas $0-$ $15 \%$, S. ovate; 6 - $15 \%$ dan S alba pada $11-20 \%$. Jagtap (1985) dalam Telave (2015), juga menegaskan bahwa $S$. caseolaris tumbuh pada zona oligohaline dan limnetic dengan kisaran salinitas yang rendah, yaitu 6-7\%.

\section{Kerapatan Jenis Mangrove}

Kerapatan jenis mangrove yang diteliti terdiri dari beberapa tingkatan yaitu tingkatan pohon, anakan dan semai. Dari keseluruhan stasiun penelitian, nilai kerapatan jenis mangrove tertinggi pada tingkat pohon yaitu Xylocarpus granatum sebanyak 1.867 ind/ha (Stasiun I) dan Sonneratia spp. sebanyak $1.333 \mathrm{ind} / \mathrm{ha}$ (Stasiun III), sedangkan tumbuhan non-mangrove tertinggi yaitu Nypa fruticans sebanyak 3.733 ind/ha (Stasiun II).

Kerapatan jenis tertinggi tingkat anakan yaitu Sonneratia spp. Sebanyak $1.733 \mathrm{ind} /$ ha (Stasiun III), Rhizopora spp. sebanyak 1.200 ind/ha (Stasiun II), dan Bruguiera gymnorrhizasebanyak 667 ind/ha (Stasiun I). Kerapatan jenis tertinggi tingkat semai yaitu Sonneratia spp. 
Sebanyak 26.667 ind/ha (Stasiun III), dan Bruguiera gymnorrhiza sebanyak 20.000 ind/ha (Stasiun I).

Secara keseluruhan, Xylocarpus granatum merupakan spesies mangrove dengan nilai kerapatan jenis tingkat pohon tertinggi, sedangkan Bruguiera gymnorrhiza merupakan spesies mangrove dengan nilai kerapatan jenis tingkat pohon, anakan dan semai terendah yang ditemukan pada lokasi penelitian. Sonneratia spp. merupakan spesies mangrove dengan nilai kerapatan jenis tingkat anakan dan semai tertinggi yang ditemukan pada lokasi penelitian.

Tingginya nilai kerapatan jenis Xylocarpus granatum dikarenakan kondisi salinitas yang ditemukan di kawasan pesisir Kota Mukomuko tergolong rendah dan payau jika dibandingkan dengan kondisi salinitas di kawasan pesisir lain pada umumnya. Menurut Noor dkk. (2006) jenis Xylocarpus granatum dapat tumbuh di sepanjang pinggiran sungai dan lingkungan payau lainnya yang tidak terlalu asin.

\section{Frekuensi Jenis}

Frekuensi jenis mangrove yang diteliti terdiri dari beberapa tingkatan yaitu tingkatan pohon, anakan dan semai. Dari keseluruhan stasiun penelitian, frekuensi jenis mangrove tertinggi pada tingkat pohon yaitu Sonneratia spp. sebanyak $1 \mathrm{ind} / \mathrm{m}^{2}$ dengan frekuensi relatif jenis sebesar 75\% (Stasiun III) dan Bruguiera gymnorrhiza sebanyak 0,67 $\mathrm{ind} / \mathrm{m}^{2}$ dengan frekuensi relatif jenis sebesar $40 \%$ (Stasiun I), sedangkan untuk tumbuhan non-mangrove tertinggi yaitu Nypa fruticans sebanyak $0,67 \mathrm{ind} / \mathrm{m}^{2}$ dengan frekuensi relatif jenis sebesar $67 \%$ (Stasiun I). Frekuensi jenis tertinggi tingkat anakan dan semai yaitu Sonneratia spp. sebanyak $1 \mathrm{ind} / \mathrm{m}^{2}$ (Stasiun III, anakan), dan $0,67 \mathrm{ind} / \mathrm{m}^{2}$ (Stasiun III, semai) dengan frekuensi relatif jenis sebesar $100 \%$.

Secara keseluruhan, Sonneratia spp. memiliki nilai frekuensi jenis tertinggi pada semua tingkatan baik pohon, anakan dan semai. Hal ini menunjukkan bahwa Sonneratia spp. memiliki penyebaran jenis dan keberadaan lebih tinggi di kawasan pesisir Kota Mukomuko. Penyebaran jenis Sonneratia spp. ini ditentukan juga oleh kondisi lingkungan, seperti kondisi substrat dan salinitas yang memungkinkan untuk pertumbuhan mangrove tersebut secara lebih optimal di kawasan pesisir Kota Mukomuko.

\section{Penutupan Jenis}

Nilai penutupan jenis tertinggi tingkat pohon di stasiun I terdapat pada jenis Xylocarpus granatum, sebesar 103,22 dengan nilai penutupan relatif jenis sebesar 96,43 \%. Kemudian diikuti oleh Rhizopora spp.sebesar 1,67 dengan nilai penutupan relatif sebesar 1,56\%, Sonneratia spp. 1,62 dengan penutupan relatif 1,51\%, dan Bruguiera gymnorrhiza sebesar 0,53 dengan penutupan relatif jenis sebesar 0,5\%. 
Pada Stasiun II dan III hanya ditemukan satu jenis mangrove sejati. Pada stasiun II adalah jenis Rhizopora spp. dengan nilai penutupan jenis sebesar 5,1 dan penutupan relatif sebesar $100 \%$ sedangkan pada stasiun III adalah jenis Sonneratia spp. dengan nilai penutupan jenis sebesar 11,1 dan penutupan relatif sebesar $100 \%$.

Tingginya nilai penutupan jenis Xylocarpus granatum pada stasiun I dikarenakan komposisi jenis dan keberadaannya relatif lebih tinggi dan memiliki ukuran lingkar batang pohon lebih besar jika dibandingkan dengan jenis lainnya, sedangkan di stasiun II dan III hanya ditemukan satu jenis mangrove sejati sehingga jenis yang ditemukan seperti Rhizopora spp.(Stasiun II) dan Sonneratia spp. (Stasiun III) memiliki nilai penutupan jenis relatif tertinggi sebesar $100 \%$ pada masing-masing lokasi penelitian. Hal inidikarenakan tidak ada komposisi jenis lainnya yang ditemukan di lokasi tersebut.Nilai penutupan jenis mangrove berhubungan erat dengan ukuran lingkar batang pohon mangrove dari masing-masing jenis. Menurut Ghufran dan Kordi (2012), jika diameter pohon berukuran besar maka akan memiliki nilai penutupan yang lebih besar.

Penutupan jenis mangrove di kawasan pesisir Kota Mukomuko tergolong baik. Hal ini dapat dilihat dari nilai penutupan jenis relatif yang ditemukan pada keseluruhan stasiun penelitian sebesar $>75 \%$. Menurut KepMen LH No. 201 Tahun 2004 kriteria penutupan jenis pada nilai > 75\% maka tergolong dalam kategori baik.

\section{Indeks Nilai Penting}

Indeks Nilai Penting (INP) mangrove yang didapatkan terdiri dari beberapa tingkatan yaitu tingkatan pohon, anakan dan semai. Kisaran indeks nilai penting (INP) mangrove untuk tingkat pohon, anakan dan semai berturut-turut yaitu berkisar antara 22,11-265,9, 91,67-200 dan 0200.

Indeks nilai penting (INP) mangrove tingkat pohon pada stasiun I terdapat pada jenis Xylocarpus granatum yang memiliki pengaruh dan peran yang besar dalam komunitas mangrove sebesar 226,76, sedangkan ketiga jenis lainnya yaitu Rhizopora spp., Sonneratia spp. dan Bruguiera gymnorrhiza memiliki pengaruh lebih kecil dalam komunitas mangrove dengan persentase berturur-turut yaitu sebesar 28,01, 23,12 dan 22,11. Stasiun II, nilai penting tertinggi terdapat pada jenis Nypa fruticans sebesar 164,1 dan stasiun III jenis Sonneratia spp. memiliki nilai penting tertinggi yaitu sebesar 265,9.

Indeks nilai penting (INP) mangrove tingkat anakan dan semai pada stasiun I ditemukan jenis Bruguiera gymnorrhiza dengan nilai sebesar 108,33 (tingkat anakan) dan 200 (tingkat semai) kemudian diikuti oleh Sonneratia spp. dengan nilai 91,67 (tingkat anakan). Stasiun II, indeks nilai penting (INP) tingkat anakan tertinggi terdapat pada jenis Rhizopora spp. sebesar 200, sedangkan untuk kategori tingkat semai tidak ditemukan. Stasiun III, indeks nilai penting (INP) mangrove tingkat anakan 
dan semai ditemukan pada jenis Sonneratia spp. dengan nilai sebesar 200.

Hasil indeks nilai penting (INP) mangrove memperlihatkan adanya perbedaan nilai INP dari tiap tingkatan yaitu baik tingkatan pohon, anakan dan semai. Hal ini menggambarkan bahwa pengaruh suatu jenis dalam komunitas mangrove berbeda dari setiap tingkatan. Untuk tingkat pohon memiliki INP tetinggi jika dibandingkan dengan tingkat anakan dan semai, hal ini dipengaruhi oleh nilai penutupan jenis yang lebih besar sehingga menghasilkan INP yang lebih tinggi. Menurut Odum (1993) dalam Raymond $d k k$. (2010) pengaruh suatu populasi terhadap komunitas dan ekosistem tidak hanya bergantung pada spesies dari organisme yang terlibat tetapi bergantung juga pada jumlah atau kepadatan populasi.

Secara keseluruhan, indeks nilai penting (INP) mangrove di kawasan pesisir Kota Mukomuko memberikan peranan penting terhadap wilayah pesisir. Hal ini terlihat dari nilai penting pada beberapa vegetasi mangrove di setiap stasiun penelitian sebesar $\geq 200$.

\section{Indeks Dominansi (D) dan Indeks Keanekaragaman ( $\left.\mathrm{H}^{\prime}\right)$}

Kisaran nilai indeks dominansi (D) pada setiap stasiun penelitian yaitu berkisar antara 0,82-0,95. Nilai indeks dominansi yang didapatkan tergolong tinggi, dimana indeks dominansi secara keseluruhan hampir mendekati 1. Odum (1993) mengemukakan bahwa jika nilai dominansi mendekati 1 berarti terdapat jenis yang mendominasi jenis lainnya atau komunitas berada dalam kondisi labil, hal ini dikarenakan adanya tekanan ekologis pada wilayah tersebut. Indriyanto (2006) menyatakan bahwa jika indeks dominansi tinggi, maka dominansi (penguasaan) terpusat (terdapat) pada satu spesies.

Kisaran nilai indeks keanekaragaman $\left(\mathrm{H}^{\prime}\right)$ pada setiap stasiun penelitian yaitu berkisar antara 0,12-0,4. Nilai indeks keanekaragaman $\left(H^{\prime}\right)$ yang didapatkan tergolong rendah. Hal ini menunjukkan bahwa vegetasi mangrove di kawasan pesisir Kota Mukomuko lebih dominan pada satu jenis mangrove tertentu. Menurut Indriyanto (2006) keanekaragaman spesies juga dapat digunakan untuk mengukur stabilitas komunitas, yaitu kemampuan suatu komunitas untuk menjaga dirinya tetap stabil.Berdasarkan kriteria yang dikemukakan oleh Bengen (2000) bahwa secara umum nilai indeks keanekaragaman jenis vegetsi mangrove di kawasan pesisir Kota Mukomuko tergolong rendah dengan nilai $\mathrm{H}^{\prime}<2$.

\section{Parameter Ekologi Ekosistem Mangrove}

Kondisi parameter ekologi di setiap stasiun penelitian tergolong baik bagi pertumbuhan mangrove, baik kondisi suhu, salinitas, $\mathrm{pH}$, oksigen terlarut (DO) dan kecerahan perairan (Tabel 2). 
Tabel 2. Kisaran nilai rata-rata parameter lingkungan di Lokasi Penelitian

\begin{tabular}{llcccc}
\hline \multirow{2}{*}{ Lokasi Penelitian } & \multicolumn{5}{c}{ Nilai Rata-rata } \\
\cline { 2 - 6 } & $\begin{array}{l}\text { Suhu } \\
\left({ }^{\circ} \mathrm{C}\right)\end{array}$ & $\begin{array}{c}\text { Salinitas } \\
(\mathrm{o} / \mathrm{oo})\end{array}$ & $\mathrm{pH}$ & $\begin{array}{c}\mathrm{DO} \\
(\mathrm{ppm})\end{array}$ & $\begin{array}{c}\text { Kecerahan } \\
(\mathrm{cm})\end{array}$ \\
\hline Bandar Ratu & $\begin{array}{l}26,7- \\
27,2\end{array}$ & $4-5$ & $6,3-6,4$ & $8,0-8,4$ & 22 \\
Ujung Pandang & $\begin{array}{l}27,2- \\
\text { 25,3 - }\end{array}$ & $4-5$ & $6,7-7,2$ & $2,2-9,2$ & 22 \\
Pasar & 27,3 & & & & 22 \\
Mukomuko & $30,0-$ & $4-5$ & $6,8-7,1$ & $4,4-7,9$ & 22 \\
\hline $\begin{array}{l}\text { Standar Baku } \\
\text { Mutu*) }\end{array}$ & 31,0 & & & & \\
\hline Keterangan : KEMENLH (1988) & & & & & \\
\hline
\end{tabular}

Salinitas adalah salah satu fitur lingkungan yang menonjol dari ekosistem mangrove dan ada banyak laporan yang menunjukkan pentingnya salinitas untuk spesies mangrove serta bukti bahwa berbagai mangrove mungkin memiliki toleransi dan salinitas optimal yang berbeda (Ball, 2002 dalam Wang et al., 2010). Berdasarkan nilai salinitas yang cukup rendah (4-5 \%o) dan lokasi tumbuhnya di sepanjang bantaran sungai, komunitas mangrove di Kota Mukomuko tergolong kelompok "mangrove wetlands". Selvam and Karunagaran (2004), sebagian besar mangrove lahan basah digenangi oleh air ber-salnitas rendah dan terkadang oleh air tawar selama musim hujan dan air payau atau laut air selama periode lainnya. Menurut hasil penelitian Giesen et.al. (2007) dalam Tanjung et al. (2017), jenis mangrove yang dapat tumbuh baik di lokasi penelitian untuk salinitas $<0,1 \mathrm{ppt}$, adalah Sonneratia caseolaris.

\section{KESIMPULAN}

Hasil analisis struktur komunitas mangrove di Kota Mukomuko menunjukan bahwa secara keseluruhan diperoleh nilai kerapatan, frekuensi jenis, tutupan dan nilai penting yang tergolong baik, namun nilai keanekaragaman jenis tergolong rendah, dikarenakan ada spesies mangrove yang lebih mendominasi di kawasan tersebut. Hal ini terlihat dari nilai indeks dominansi yang didapatkan tergolong tinggi. Vegetasi mangrove yang masih banyak ditemukan terdapat pada Kelurahan Bandar Ratu (Stasiun I), sedangkan Desa Ujung Padang (Stasiun II) dan Kelurahan Pasar Mukomuko (Stasiun III), memiliki vegetasi mangrove yang tergolong homogen. Indeks Nilai Penting (INP) menunjukkan peran penting vegetasi mangrove di kawasan pesisir Kota Mukomuko tergolong tinggi dalam menjaga lingkungan pesisir, baik tingkatan pohon, anakan maupun semai. Keberadaan vegetasi mangrove di wilayah tersebut harus tetap selalu dijaga dan dilestarikan. 


\section{DAFTAR PUSTAKA}

Bengen, D.G. 2000. Sinopsis teknis pengambilan contoh dan analisis data biofisik sumberdaya pesisir. Bogor: Pusat Kajian Sumberdaya Pesisir dan Lautan, Institut Pertanian Bogor. 88 hlm.

BPS Kabupaten Mukomuko. 2017. Kabupaten Mukomuko dalam angka tahun 2016. Badan Pusat Statistik (BPS) Kabupaten Mukomuko.

Ghufran, M dan Kordi, H. 2012. Ekosistem mangrove: potensi, fungsi dan pengelolaan.PT. Rineka Cipta, Jakarta.

Hartono, D., Zamdial Ta'alidin, Deddy Bakhtiar dan Eko Nofridiansyah. 2014. Laporan akhir identifikasi kerusakan daerah pesisir Provinsi Bengkulu. Dinas Kelautan dan Perikanan Provinsi Bengkulu, Bengkulu.

Indriyanto. 2006. Ekologi hutan. PT. Bumi Aksara, Jakarta.

Keputusan Menteri Negara Lingkungan Hidup Nomor 201. 2004. Kriteria baku dan pedoman penentuan kerusakan mangrove. KepMen LH. Jakarta. $10 \mathrm{hlm}$.

Marisa, H. and Sarno, 2015. Three Species Zonation of Sonneratia; Based on Salinity, in River Calik, South Sumatera. International Conference on Plant, Marine and Environmental Sciences (PMES-2015) Jan. 12, 2015 Kuala Lumpur (Malaysia); 100-101.

Noor,Y., Khazali, M dan Suryadiputra. 2006. Panduan pengenalan mangrove di Indonesia. Oxfam Novib, Bogor.

Odum, E.P.1993. Dasar-dasar ekologi. Terjemahan Tjahjono Samingan. Yogyakarta: Gadjah Mada University Press.

Raymond, G., Harahap, N dan Soenarno. 2010. Pengelolaan Hutan Mangrove Berbasis Masyarakat Di Kecamatan Gending, Probolinggo. Agritek, Vol.18 No.2 April 2010 (185-200).

Selvam, V and V.M. Karunagaran, 2004. Ecology and Biology of Mangroves Orientation Guide. M.S. Swaminathan Research Foundation 3rd Cross Street, Institutional Area Taramani, Chennai 600113 , India. 61 p.

Sofian, A., N. Harahab, dan Marsoedi. 2012. Kondisi dan manfaat langsung ekosistem mangrove desa penunggul keca-matan nguling kabupaten pasuruan. El-Hayah, 2(2):56-63. 
Sykes, H., 2007. Mangrove Management Plan for Vulani Islands Stage 1: General Mangrove Management. Marine Ecology Consulting, Fiji. 17 p.

Tanjung, Riski, Nurul Khakhim, dan Rustadi, 2017. Kajian Fisik Pesisir Kulon Progo untuk Penentuan Zona Kawasan Mangrove dan Tambak Udang. Majalah Geografi Indonesia Vol. 31, No. 2, September 2017 (22 - 32).

Telave, Ajit B., 2015. Ecophysiological studies on Sonneratia L. from the coast of Maharashtra, India. Indian Journal of Geo-Marine Science, Vol. 44 (8), August 2015, pp. 1239-1244.

Wang, L., Meirong Mu, Xiaofei Li, Peng Lin and Wenqing Wang, 2010. Differentiation between true mangroves and mangrove associates based on leaf traits and salt contents. Journal of Plant Ecology Advance Access published March 29, 2010; 1-10. 